\title{
SITUATING TSITSERNAKABERD: THE ARMENIAN GENOCIDE MUSEUM IN A GLOBAL CONTEXT
}

\author{
Rebecca Jinks
}

This article sets the Armenian Genocide Museum-Institute, and the Tsitsernakaberd memorial complex, into the global context of genocide memorial museums. It discusses architectural and design features as well as the museum's first permanent exhibition (1995-2013, with updates and additions), and argues that while the museum and memorial complex conform to global trends in many ways, the museum exhibition itself showed some differences. Specifically, it seems that the experience of longstanding genocide denial and the continued international non-recognition of the genocide in the early 1990s means that the exhibition had to take on the 'burden of proof' and, unlike in other museums, was almost wholly devoted to constructing a 'case for genocide'

A decade into the twenty-first century, the global 'memory boom' shows no sign of slowing down - especially regarding 'difficult pasts': every year, more books are written, films made, and commemorative ceremonies held. Alongside these, there has also been a global 'boom' in the building of memorial museums; almost every major genocide or authoritarian regime in the twentieth century now has a museum or a memorial dedicated to remembering and to educating subsequent generations. In this article I will set the Armenian Genocide MuseumInstitute (AGMI) into the global context of genocide museums, those guardians of memory and meaning. ${ }^{1}$ Just as comparative historical analysis has enhanced our understanding of both the specificities of the Armenian genocide and the phenomenon of genocide more generally, ${ }^{2}$ so too can a comparative approach to the memorialisation of genocide illuminate how contexts influence remembrance and representation, and the processes by which the

1. This article arises from the research I was able to complete at the Armenian Genocide MuseumInstitute, whilst holder of the Museum-Institute's first Raphael Lemkin Scholarship. I am immensely grateful to the Director, Hayk Demoyan, Suren Manukyan, Asya Darbinyan, and the rest of the staff at AGMI for the opportunity and the support I received during my stay.

My doctoral thesis (2014), for which I held the Reid Scholarship at Royal Holloway, University of London, is entitled 'Representing Genocide: The Holocaust As Paradigm?', and is a comparative analysis of cultural representations of the Armenian, Jewish, Cambodian, Bosnian and Rwandan genocides, using film, literature, photography and memorialisation as sources. Some of the research for this article was generously funded by the Friendly Hand.

To cite this article: Rebecca Jinks, "Situating Tsitsernakaberd: The Armenian Genocide Museum in a Global Context," International Journal of Armenian Genocide Studies 1:1 (2014): 39-51.

2. Some good examples include Donald Bloxham, The Great Game of Genocide: Imperialism, Nationalism and the Destruction of the Ottoman Armenians (Oxford: Oxford University Press, 2005); Robert Melson, Revolution and Genocide: On the Origins of the Armenian Genocide and the Holocaust (Chicago: University of Chicago Press, 1992); Hans-Lucas Kieser and Dominick J. Schaller, eds., Der Völkermord an der Armeniern und die Shoah (Zürich: Chronos, 2002); Hilmar Kaiser, "Genocide at the Twilight of the Ottoman Empire," in The Oxford Handbook of Genocide Studies, eds. Donald Bloxham and A. Dirk Moses (Oxford: Oxford University Press, 2010). 
events are made meaningful to the descendants of the victims and the rest of the world in the aftermath. ${ }^{3}$ The vast majority of research into memory and representation has been done within the remit of Holocaust Studies, but this memory boom especially allows us to expand and refine our understanding and analyses of how circumstances shape the remembrance of traumatic events. In this vein, I argue here that although the museum, and the Tsitsernakaberd memorial complex in which it is located, is in many ways comparable to other memorial museums - in particular the purpose-built Holocaust museums in Europe, America, and Israel - the Turkish denial of the genocide had a deep impact, whether subconsciously or not, upon the design of the permanent exhibition. This exhibition ran from 1995 to 2013, with various updates and additions as further donations were made to the institution, and (at the time of writing) is being substantially revised and extended for the centenary anniversary in 2015.

The original memorial complex was completed in 1967. In Soviet Armenia before 1965, the genocide had never been officially or publicly memorialised as a national loss; on the fiftieth anniversary, crowds congregated on Lenin Square in central Yerevan and eventually public protest broke out against the continual non-remembrance of the genocide. The Genocide Memorial was erected quite shortly thereafter on the hill of Tsitsernakaberd, just outside the city centre. Designed by architects Sashur Kalashyan and Artur Tarkhanyan, it deployed the style of Soviet war memorials, and consisted of a huge split obelisk and a massive grey stone mausoleum, made of twelve stone slabs, with an eternal flame set into its centre. ${ }^{4}$ Every year, it is the site of the official commemoration on April 24th. The museum itself was not opened until 1995, the eightieth anniversary of the genocide. The exhibition was designed by the museum director and other Armenian historians, and its narration of genocide and national loss was shaped by the very immediate contexts of, firstly, Armenia's nation- and state-building process following its independence from the Soviet Union in 1991, and secondly, the conflict with Azerbaijan over the territory of Nagorno-Karabagh ${ }^{5}$ (as well as a severe economic crisis). In the national context, then, the exhibition was both responding to and shaping the new layers of meaning added to the genocide's fundamental place in Armenian identity.

On an international level, as with the survivors of other genocides and their descendants, the memory of the genocide is very present amongst Armenians both within Armenia and in the diaspora - although there are, obviously, differences in remembrance and its relationship with ethnic identity between different communities across the globe - and this memory is galvanised by, and often articulated in opposition to, Turkish denial. During

3. See Paul Williams, Memorial Museums: The Global Rush to Commemorate Atrocities (Oxford and New York: Berg, 2007).

4. See Tsypylma Darieva's excellent article "'The road to Golgotha': Representing loss in post-socialist Armenia," Focaal - European Journal of Anthropology 52 (2008): 92-108 for an extended analytical description. See also Darieva, "From Silenced to Voiced: Changing Politics of Memory of Loss in Armenia," in Representations on the Margins of Europe: Politics and Identities in the Baltic and South Caucasian States, edited by Tsypylma Darieva and Wolfgang Kaschuba (Frankfurt/New York: Campus Verlag, 2007), 65-88.

5. See Harutyun Marutyan, Iconography of Armenian Identity: The Memory of Genocide and the Karabagh Movement (Yerevan: Gitutyun Publishing House of NAS RA, 2009). 
the first half of the 1990s, when this exhibition was being designed, the official Turkish history and much of the Turkish historiography still peddled a narrative of 1915 which argued that the subversive acts of Armenians, encouraged by Western meddling in the Ottoman empire, justified the Armenian 'relocations' and massacres. ${ }^{6}$ Equally, Armenia's relations with Turkey were increasingly strained following the Nagorno-Karabagh war in 1993. Internationally, it was Bernard Lewis, the American historian of Modern Turkey, who was holding court in the press - he and 68 other international scholars had signed an advertisement which appeared in the New York Times in 1985 which questioned the basis of evidence for genocide, and Lewis continued to make revisionist claims in various statements to the French press in the early 1990s; in fact only three national governments - Cyprus, Uruguay and Russia - had officially recognised the Armenian genocide by $1995 .^{7}$ These struggles over the recognition of the Armenian genocide were also somewhat overshadowed by the boom in Holocaust memorialisation in the build-up to the $50^{\text {th }}$ anniversary of the liberation of the Nazi concentration camps was occurring, reports of atrocities and camps in the former Yugoslavia were hitting the press, and, a little later, wrangles over the use of the word 'genocide' to describe the massacres in Rwanda. This was the context in which the permanent exhibition was designed: the exhibition, I will argue, was working against this denial and the hesitancy surrounding the use of the word 'genocide' to describe what happened to Armenians, by seeking to provide its international visitors with irrefutable proof of genocide.

This article is based on an extensive visit to the museum in April 2011, during which I had the chance to observe visitors' interactions with the exhibition and memorial complex both during the April $24^{\text {th }}$ commemorations and outside them, and on my research at other multiple sites and museums of genocide. In the first section of this article, I compare the design of the Tsitsernakaberd memorial complex and the architecture of the museum itself with other genocide museums, and show that in this respect it entirely conforms to global trends. I then discuss the previous permanent exhibition itself, paying particular attention to the artefacts and documents chosen to narrate the genocide, and what that suggested about the underlying message of the museum. Finally, I consider how Armenian and nonArmenian visitors, two very different memory communities, might respond to the museum.

\section{Tsitsernakaberd and the museum in comparative perspective}

In physical and formal terms, the Tsisternakaberd complex is more comparable to the United States Holocaust Memorial Museum (USHMM) in Washington, DC, Yad Vashem

6. See Donald Bloxham and Fatma Müge Göçek, "The Armenian Genocide," in The Historiography of Genocide, edited by Dan Stone (Basingstoke: Palgrave Macmillan, 2008), 344-72: 349-50.

7. More recently, alternative voices have sprung up within Turkey, and 21 governments along with various regional governments and human rights-oriented organisations have now recognised the genocide (the majority since 2000). But the Armenian genocide still occupies a somewhat awkward and peripheral position within the global memoryscape - there is a kind of 'semi-consciousness' amongst non-Armenians in the West, as historian Donald Bloxham puts it - there is only a consciousness at all because of the special relations of Christian powers with Christian suffering in the Ottoman Empire, but it is a hesitant consciousness because of denial, geopolitics, and changing perceptions of the perpetrator state. Bloxham, The Great Game of Genocide, 230. 
in Jerusalem, the Jewish Museum of Berlin, or London's Imperial War Museum (IWM) Holocaust Exhibition than to many of the other genocide museums or memorials in, for example, Bosnia, Rwanda, or Cambodia, or indeed the museums and memorials on former Nazi concentration camp sites, such as at Auschwitz or Dachau. All of these Holocaust museums (or exhibitions within museums, in the case of the IWM) are purpose-built, and have similar institutional objectives of public education, facilitating research, and collecting and maintaining archives. They are also mostly located far from the sites of suffering: although each is heavily imbued with symbolic meaning, ${ }^{8}$ they do not have quite the same emotional charge as, for example, the memorials and museums at Auschwitz, the former interrogation centre S-21 in Cambodia, the battery factory in Srebrenica where Muslim refugees were held before the men were separated and killed, or the many churches and other municipal buildings where the victims sought safety in Rwanda, many of which are now preserved as memorials. ${ }^{9}$ Yad Vashem is built on the Mount of Remembrance, near to the national cemetery where the father of Zionism, Theodore Herzl, is buried; the museum visit ends with a magnificent view over the hills of Jerusalem from the viewing platform at the end of the building, a finale to and continuation of the museum narrative's underlying (Zionist) message. ${ }^{10}$ Tsitsernakaberd is located at the top of a hill above Yerevan, visible from many areas of the city; on a clear day Mount Ararat is visible from the memorial complex. Once visitors emerge from the museum, then, this view of Ararat - that potent symbol of loss in the Armenian community - adds to and consolidates the human loss witnessed in the exhibition: where Yad Vashem offers cathartic redemption, the visit to AGMI ends with a potent reminder of loss.

Both Tsitsernakaberd and Yad Vashem are also quite extensive memorial complexes: ${ }^{11}$ there are innumerable memorials on the Yad Vashem campus besides the Historical Museum, from the Children's Memorial and the Avenue of the Righteous Among the Nations, to the numerous memorials dotted around the gardens to the Jewish victims, communities, soldiers and partisans. ${ }^{12}$ The focus of the Tsitsernakaberd complex is undoubtedly the original memorials built in 1967, the split obelisk and the massive grey stone mausoleum and eternal flame, which is gradually surrounded every April $24^{\text {th }}$ by a ring of flowers left by those on the commemorative march. But the site also holds a Memorial Alley with trees planted in memory of the victims by international delegates, and a memorial wall

8. See Darieva, "The road to Golgotha," for an overview.

9. For brief descriptions and analyses of all of these, see Williams, Memorial Museums, 10, 17-18, 18-19 and passim. The only Armenian equivalent would probably be the museum at Der-el-Zor.

10. An excellent and recent discussion of Yad Vashem can be found in Amos Goldberg, "The Jewish narrative' in the Yad Vashem global Holocaust Museum," Journal of Genocide Research 14:2 (2012): 187-213. He discusses the end-point of the museum as a cathartic narrative at 206-7.

11. The USHMM, JMB, and IWM are all built within rather than on the edge of urban spaces, and thus have less space for such an extensive complex. This is not to say that their locations are not symbolic in themselves: the USHMM is a short walk from the Mall and the White House; Libeskind's Jewish Museum is an extension to the original Jewish Museum in Berlin; London's Holocaust Exhibition is located within its war museum, also unofficially considered the 'national museum' of Britain.

12. The Yad Vashem website has an incomplete list of memorials on its campus: http://www1.yadvashem. org/yv/en/visiting/map.asp. 
which on one side is carved with the memorial geography of Armenian deportation and suffering, from Constantinople to Der-el-Zor, and on the other holds earth from the graves of prominent non-Armenians who helped the Armenians during the genocide, including Franz Werfel and Armin Wegner, and most recently on April 21 2011, Maria Jacobsen and Alma Johansson. Near to the wall are memorials, in the form of traditional khachkars, to the memory of Armenian victims of massacres in Sumgait and Baku, as well as to the defenders of Gandzak (Gence). ${ }^{13}$ Both complexes are heavy with symbolism, then, drawing together victims and altruistic saviours in the service of an ethnic and transnational remembrance.

In a broader sense, one can also relate Israel's national memorial landscape to Armenia's: across each, one finds smaller memorials dotted around the landscape, generally funded and commissioned by individuals and local communities (some or all of whom may have been survivors) or municipal authorities. ${ }^{14}$ In accordance with the victim group's central tenets of remembrance, the majority are monuments which commemorate suffering and loss, but some are dedicated to the well-known acts of resistance, such as the two largest resistance memorials, Beit Lohamei HaGeta'ot (Ghetto Fighters' House Museum) and the monument in Musaler (Musa Dagh) village in Armavir province; both are smaller museums telling the tale of the best-known act of resistance, although the Israeli museum is much larger and also holds an extensive archive. ${ }^{15}$ The crucial difference between the Israeli and Armenian memorial landscape is that while Israeli memory of the Holocaust has, obviously, changed since 1945, Soviet rule had a much deeper impact upon the nature of Armenian remembrance until 1991. Many of the Armenian memorials were built in the decade or so following the fiftieth anniversary demonstrations in 1965, and had to conform to the dictats of socialist remembrance - all were designed in what was effectively still a socialist realist style, although the usual tropes of war and loss now signified a very different kind of loss - whereas those built after 1991 tend to follow the more traditional style of a khachkar and inscription with the date of 1915.

Inside the Museum at Tsitsernakaberd itself, the architecture and aesthetic design too is comparable to these Western-designed, purpose-built museums. In the 1990s and 2000s a spate of Holocaust museums were opened - the USHMM in 1993, the Jewish Museum Berlin in 1999, the IWM Holocaust Exhibition in 2000, and the Shoah Museum in Paris, the Memorial to the Murdered Jews of Europe in Berlin, and the new Yad Vashem Holocaust History Museum in 2005 - all of which eschewed the traditional museum architecture of big open spaces, white walls, and artefacts in display cases. ${ }^{16}$ Instead, these museums

13. See in general Darieva, "The Road to Golgotha," 96-104.

14. On the memorial landscape in Armenia see $\mathrm{http}: / /$ www.armenian-genocide.org/memorials.html and Memorials of Sorrow, Remembrance and Struggle (Yerevan: Ministry of Diaspora of the Republic of Armenia, 2010). On Israel, see James E. Young, The Texture of Memory: Holocaust Memorials and Meaning (New Haven/London: Yale University Press, 1993), 209-81.

15. The monument/museum at Musaler is visible here: http://www.armenian-genocide.org/Memorial.17/ current category.52/offset.10/memorials detail.html. For Beit Lohamei HaGeta'ot, see http://www.gfh. org.il/Eng/.

16. For an excellent overview on these broad changes in museology, see Sharon Macdonald, "Expanding Museum Studies: An Introduction," in A Companion to Museum Studies, ed. Sharon MacDonald (Oxford: Blackwell, 2006): 1-12, and the rest of the essays in that volume. 
together marked the inauguration of a new commemorative aesthetic, what I call an 'affective architecture', where the interior space and decoration of the building is designed in order to elicit certain sensory and emotional reactions, which chime with the exhibition or memorial's content and intended meaning. One of the most famous examples of this affective architecture is found in Daniel Libeskind's Jewish Museum Berlin, where the tight, twisted, and disorienting spaces create some of the feeling of claustrophobia and disorientation which the victims themselves felt; ${ }^{17}$ the same techniques of low-ceilinged, constrictive, and dark spaces are used in all of the above-mentioned Holocaust museums, and indeed also in other museums dedicated to conflict and loss - from the Kigali National Genocide Museum in Rwanda (designed under the auspices of the UK charity Aegis Trust) to the Imperial War Museum North in Manchester. ${ }^{18}$

Built and opened in 1995, at a roughly similar time to the earlier museums of this trend, the AGMI used many of the same techniques. There are none of the architectural twists and turns - the exhibition was housed in a large, smooth circle built around an inner courtyard, although one could say that the zig-zag progress visitors made from one side of the curve to the other echoes, in a symbolic sense, the wandering paths taken by the deportees in 1915 - but the rooms devoted to the genocide period had a constricted feel, and the museum also used dim lighting, colour, and physical descent to accentuate the visitor's feeling of unease and unsettlement. At Yad Vashem, the USHMM, and the IWM, the exhibitions begin with prewar Jewish life on the top floor of the exhibition (or a physically higher level), and the décor changes to blacks and greys, and the lighting is dimmed, as visitors literally and symbolically descend to lower floors to reach the part of the exhibition which deals with the ghettos, deportations, and the concentration camps. At Yad Vashem, the floor of the long, thin building then rises again into the triumphal viewing platform mentioned above. The AGMI museum exhibition made use of colour, lighting, and physical space in much the same way: one descended into the museum from the memorial complex outside, and then a few more steps into the exhibition itself. The first square stone hall, which contained a huge map of 'historic Armenia' and display cases with artefacts showing the vibrancy of pre-WWI Armenian society, was relatively spacious and has some natural light from a skylight above; but in the main curved exhibition hall, which documented the deportations and atrocities, the walls were much darker, the ceilings lower, the lighting dim - the only windows to the outside shaped as thin Christian crosses - and large reproductions of atrocity photographs taken mostly by Armin Wegner loomed over the display cases and the visitors. At the end of the exhibition, one ascended again to the light of the reception hall and then the memorial complex outside, with its view of Ararat. Like its contemporaries, then, the AGMI also attempts to enhance the message of its exhibition with an affective architecture.

17. There is a huge literature on the architecture of Libeskind, but begin with James E. Young, At Memory's Edge: After-Images Of the Holocaust in Contemporary Art and Architecture (New Haven/London: Yale University Press, 2000), chapter 6 (“Daniel Libeskind's Jewish Museum in Berlin"), 152-183, and other relevant essays in the book. Libeskind has used a similar style for the Danish Jewish Museum, Copenhagen, and the Felix-Nussbaum-Haus in Osnabrück, Germany.

18. Although it is worth noting that there are not many purpose-built museums to other genocides Kigali is an exception - since most are housed in the sites where torture and murder took place. 


\section{The exhibition}

However, there were subtle differences between the content and the underlying thrust of the AGMI's 1995-2013 exhibition and those of other Holocaust and genocide museums and these differences, I would argue, were a measure of the (in some ways quite distortive) impact of denial on the representation and the historiography of the Armenian genocide. ${ }^{19}$ Although the exhibition itself did not discuss denial, the unremitting stream of atrocity photographs, reproduction of orders from the Ottoman Turk authorities, and harrowing eyewitness reports - uninterrupted by the temporary and partial relief which survivor testimonies or more detailed analysis of individual case studies can bring - amounted, cumulatively, to a 'case' for genocide and a refutation of denial.

Over the past few decades, a growing trend in Holocaust research and representation has sought to integrate the experiences and voices of the victims alongside the words and deeds of the perpetrators, for the historical perspective they add, for the insight they give into the victims' suffering, and for the empathy they create amongst visitors for the victims. ${ }^{20}$ The Holocaust museums I have mentioned above all construct a careful historical narrative of the events, supported by documentation and artefacts, and then intersperse these with excerpts of survivor testimony, with individual or family photographs of victims, and with poignant personal belongings (for example, shoes, clothing, pairs of glasses, a diary, a pipe - in a smaller version of the famous rooms full of shoes, suitcases, and hair on display at Auschwitz). ${ }^{21}$ Many also list the names of the victims, and perhaps their birth and death dates, on walls and in books, to try to communicate the sheer scale of loss and destruction. ${ }^{22}$ All of these techniques individualise the victims, and invite

19. Academic scholarship is beginning to move past the burden placed on it by the need to refute denial and prove genocide. For a recent historiographical analysis, see Bloxham and Göçek, "The Armenian Genocide". For a brave attempt to move beyond these divisions, see the essays in A Question of Genocide: Armenians and Turks at the End of the Ottoman Empire, edited by Norman M. Naimark, Ronald Grigor Suny, and Fatma Müge Göçek (Oxford: Oxford University Press, 2011).

20. Debate within Holocaust historiography has been kicked off by Saul Friedländer's efforts to write an 'integrated' history of the Holocaust, in his two-volume work, Nazi Germany and the Jews: The Years of Persecution, 1933-1939 (London: Weidenfeld and Nicholson, 1997) and The Years of Extermination, 1939-1945 (London: Weidenfeld and Nicholson, 2007). Dissatisfied with the tendency in Holocaust histories to write using only German sources, he argued that including the voices of the victims (taken from contemporary diaries) would 'tear through seamless interpretation and pierce the (mostly involuntary) smugness of scholarly detachment and "objectivity" (Years of Extermination, xxvi).

21. There are many studies of these displays in different museums. On the use of individual and family portraits to elicit identification, see Marianne Hirsch, Family Frames: Photography, Narrative and Postmemory (Cambridge, MA: Harvard University Press, 1997); on the use of oral testimony (specifically in the IWM), see Tony Kushner, "Oral History at the Extremes of Human Experience: Holocaust Testimony in a Museum Setting," Oral History 29:2 (2001): 83-94: on the display of objects, see Oren Baruch Stier, Committed to Memory: Cultural Mediations of the Holocaust (Amherst/Boston: University of Massachusetts Press, 2003): 110-49. More generally, see Andrea Liss, Trespassing through Shadows: Memory, Photography and the Holocaust (Minneapolis/London: University of Minnesota Press, 1998).

22. Yad Vashem has a Hall of Names, where they hope to collect the names of all 6 million dead (roughly 3 million have been collected thus far); the Shoah Museum in Paris has stone walls engraved with the names of Jewish deportees from France; displayed in the Jewish Museum Berlin are the Gedenkbücher, filled with the names of all those deported from Berlin; in a room in the Ort der Information underneath 
visitors of all nationalities, ethnicities, and ages to identify with their plight; in this, they act as a balance to the more shocking and disturbing images of suffering and death, and humanise the presentation. As Louis Bickford and Amy Sodaro have recently noted, this individualising approach is not limited to Holocaust museums, and many other memorial museums around the globe now also try to create empathy in this way. ${ }^{23}$

Although the first hall of the AGMI exhibition displayed some such artefacts in its coverage of pre-war Armenian social and cultural life - photographs of sports teams, of schoolchildren, of community leaders (all of whom, we assume, were swept up into the genocide) - the main part of the exhibition used only photographs of suffering and destruction, the cold orders of the Young Turks, and copies of reports and books written by western diplomats, missionaries, and academics. ${ }^{24}$ There was, in fact, very little narrative in the exhibition (the guided tours, available in Armenian, English, Russian, French, and German, provided this); most of the display cases contained a few paragraphs (in four languages) outlining the basic history of the events under discussion - the Hamidian massacres of 18946, the 1909 massacres, the murder of the intellectual and religious leaders, the deportations, foreign witnesses and their reactions, and the destruction of Armenian churches and other cultural heritage - but there was no comprehensive causal or explanatory narrative threaded through the exhibition. Visitors to the exhibition were therefore encouraged to spend time studying the images and documents, as the tangible remains of what happened.

Of course, in one sense, these artefacts merely illustrated the progression of violence against the Armenians in the crumbling Ottoman Empire, but it is worth noting that they all provide what is classically recognised as 'hard evidence' for genocide, and, in the absence of any 'softer' evidence (in the form of emotive displays of the victims' belongings, family photographs, or oral testimony from survivors), amount to something akin to an evidence docket. As visitors entered the exhibition, a panel on the wall to the left in the entrance hall quoted the UN definition of genocide as ratified in the Genocide Convention of 1948, which

the Memorial to the Murdered Jews of Europe, two voices list the names and brief biographies of victims; the USHMM displays glass panels with Jewish first names engraved on them. This trend towards naming the victims individually is not limited to the Holocaust; the Vietnam Veterans Memorial in Washington, DC is a well-known and provocative example. On this, and more generally, see Marita Sturken's masterful Tangled Memories: the Vietnam War, the AIDS Epidemic, and the Politics of Remembering (Berkeley, CA: University of California Press, 1997), chapters 2, 6, and passim.

23. Louis Bickford and Amy Sodaro, "Remembering Yesterday to Protect Tomorrow: The Internationalisation of a New Commemorative Paradigm," in Memory and the Future: Transnational Politics, Ethics and Society, eds. Yifat Gutman, Adam D. Brown and Amy Sodaro (Basingstoke: Palgrave Macmillan, 2010). There are also walls of names at the Srebrenica-Potočari Memorial Museum in Bosnia, and at a few Rwandan memorials (although these are only very partially completed). The Tuol Sleng Genocide Museum in Phnom Penh, Cambodia, has famously filled room after room with prints of the photographs of victims taken by the Khmer Rouge when they entered the torture centre. Both the Kigali Genocide Memorial Centre and the Srebrenica-Potočari Memorial Museum display the personal possessions of victims in much the same style as Holocaust museums.

24. Of course, the nature of the Armenian genocide (deportations from homes, accompanied by robbery and looting) means that survivors were left with far fewer possessions which, in turn, could be donated and displayed in the Museum (there is a roughly similar situation with the Cambodian genocide; the Tuol Sleng Genocide Museum displays only the clothes of the victims and the photographs that were taken as they entered the prison). 
briefed visitors for the exhibition itself. In the main exhibition hall, above each display case a large reproduction of one or more photographs were hung, most of which were taken from the collection of Armin Wegner. Almost without exception, they documented deportation, starvation, execution, and mass death; these are precisely the types of images pragmatically accepted as historical evidence in both public and legal fora. ${ }^{25}$ Likewise, the 'smoking guns' were reproduced by the exhibition - large facsimiles of an order from Enver Pasha and two telegrams from Talaat Pasha, ordering the extermination of the Armenians and its concealment from the outside world.

Aside from the photographs, the main descriptions of the deportations and killings were then in fact provided by the written reports of foreign diplomats and missionaries. A substantial proportion of the display cases exhibited examples of news reports in the foreign press, telegrams from diplomats and missionaries (often drawing on testimony from contemporary eyewitnesses), speeches in foreign parliaments, and the published diaries or memoirs of these foreign witnesses (as well as the biographies of a select few). Many of the passages selected for display repeated the phrase 'extermination of the Armenian race' or 'destroy the Armenian race as a race' - an echo not just of the Young Turk leaders' orders, but also of the legal definition of genocide which was to pass into international law thirty-three years later. ${ }^{26}$ In one sense, this functioned as a reminder of the sense of outrage and responsibility the West felt for Armenians at the time, ${ }^{27}$ but, rereading this from an evidentiary point of view, one could note that many more display cases were given over to foreign reports and scholarly books on the genocide than those displaying survivor testimonies - and, indeed, since the majority of testimonies were published memoirs, only their front covers or title pages were visible behind the glass,

25. On the photographs of the Armenian genocide, see Tessa Hofmann and Gerayer Koutcharian, "'Images that Horrify and Indict': Pictorial Documents on the Persecution and Extermination of Armenians from 1877 to 1922," Armenian Review 45: 1-2 (1992): 53-184, and Sybil Milton, "Armin T. Wegner: Polemicist for Armenian Rights and Jewish Human Rights," Armenian Review 42:4 (1989): 17-40. There are, of course, many intermediate difficulties with using historical photographs as evidence, including the importance of knowing the identity of the photographer, the date, and the location (perhaps the photographer most especially, since his/her perspective on and reaction to the events directly influences the content and framing of the image); see, in the Armenian context, the essays by Abraham D. Krikorian and Eugene Taylor, available at http:// groong.usc.edu/orig/Probing-the-Photographic-Record.html. But there are also knottier problems related to what such photographs cannot depict. In the strict legal sense, photographs cannot prove genocide itself, since one cannot photograph intent (for an analogous argument in the context of the Holocaust, see Judith Keilbach, "Photographs, Symbolic Images, and the Holocaust: On the (Im)Possibility Of Depicting Historical Truth," History and Theory 48:2 (2009): 54-76, especially pages 60-1). Individually, these images show deportations, starvation, execution, and mass death; cumulatively, they show the outcome of a systematic policy. As genocide scholar Dirk Moses puts it, historians can 'construe intent through action'. See A. Dirk Moses, "An Antipodean Genocide? The Origins of the Genocidal Moment in the Colonization of Australia", Journal of Genocide Research 2:1 (2000): 89-106.

26. This is a striking aspect of many more documents than those on display. See, e.g., Ara Sarafian, comp. and intro., United States Official Documents on the Armenian Genocide, 1915-17 (Princeton/ London: Taderon Press in association with the Gomidas Institute, 2004).

27. Similarly, in her analysis of the meaning of transferring earth from the graves of those who helped the Armenians to Tsitsernakaberd, Tsypylma Darieva argues that the memory of the genocide is thereby converted 'from an ethnic notion of loss and death into a global memory of forgotten human loss.' Darieva, "From Silenced to Voiced," 84. 
rather than their words. Possibly foreign diplomats' telegrams and newspaper reports would be thought more 'impartial' by visitors to the museum - although there is no real reason to believe that survivors' testimony would be viewed particularly differently unless a visitor was already inclined to distrust it. ${ }^{28}$ The exhibition ended with a section on the internationally-administered refugee camps and orphanages, and the efforts to rescue women and children who had been forcibly adopted into Muslim households thus, symbolically, the rebirth of the Armenian nation - before visitors returned to the main entrance hall.

As I noted before, in some ways these artefacts were merely well-chosen illustrations of the basic and familiar narrative of the Armenian genocide. But subconsciously or not, the museum also seemed to have taken on the burden of proof. Instead of the detail of video testimonies or personal belongings and other artefacts, what visitors were given to study is hard evidence - documentation, photographs, and witness reports. Indeed, at the end of the guided tour, the guides often asked visitors to consider for themselves if this was a genocide. Returning to the main entrance hall, they were directed to look at the museum's glass-fronted inner courtyard. Laid out at their feet was a traditional grey stone khachkar, representing the Armenian victims, and the semicircular wall was divided into twelve sections, each carved with statements condemning the genocide by those foreign politicians, diplomats, and writers, representing witnesses in a courtroom. The copy of the UN Genocide Convention, which visitors passed as they entered the exhibition, hovered within eyesight on the wall; the guide asks the visitor to judge for themselves.

Of course, memorial museums dedicated to the Holocaust and other genocides also display the relevant artefacts and documentation which is evidence for genocide, but my point here is that in none of these museums does the need to prove genocide seem so insistent or urgent. Holocaust museums only display artefacts which can be reliably authenticated, so as not to provide openings for Holocaust deniers ${ }^{29}$ in Cambodia and Rwanda, the skulls and bones of victims, which are often displayed in memorials, serve as evidence against denial. ${ }^{30}$ The memorial museum to the Srebrenica

28. It is interesting to compare the use of survivor testimony in legal trials here. The Nuremberg trials, in the immediate aftermath of the war, relied mostly on Nazi documents; the lawyers prosecuting David Irving for Holocaust denial in the UK in 2000 called only historians, and no survivors, as witnesses, for fear that the defence would expose 'faults' in their memories and jeopardise the case. In contrast, the trial of Adolf Eichmann in Jerusalem in 1961 famously permitted survivors to testify at length, even if their experiences were somewhat tangential to the case itself. However, this trial (and this testimony) is widely credited with bringing the Holocaust back into the world's attention, as well as bringing about a change in how the Holocaust was perceived in Israel itself. For a general overview, see Donald Bloxham, "From Streicher to Sawoniuk: The Holocaust in the Courtroom," in The Historiography of the Holocaust, ed. Dan Stone (Basingstoke: Palgrave Macmillan, 2004): 397-419.

29. For example, the project director of the IWM's Holocaust Exhibition, Suzanne Bardgett, stated this as a concern whilst they were gathering artefacts for the exhibition. The only inauthentic object in the exhibition is a large-scale model of Auschwitz.

30. Rwanda has a different set of issues surrounding denial. Undoubtedly, there are Hutu who deny that genocide happened, but the government also instituted a law under which anyone who includes the politically moderate Hutu (who were also targeted during the genocide) as 'genocide victims' can be 
victims is an interesting comparator in this respect: Bosnian Serbs routinely deny that genocide happened, and indeed there are alternative home-made museums about 'Serbian genocide' just a short drive away. ${ }^{31}$ But the museum does not engage with this denial, and indeed is very much aimed at the Bosnian Muslim and international community: the bodies of the victims who are now interred in the cemetery across the road from the museum have been forensically identified by DNA, and the museum itself is very simple, displaying only the brief biographies of fifteen representative victims, together with a personal possessions - pipe, book, a Koran - found with them in the grave, and a film which combines an outline of the events with very emotive testimony from surviving mothers and wives of the victims. Each of these four cases of genocide, though, has international recognition, whereas, as I noted in the introduction, in the early 1990s when this exhibition was being formulated, Armenians were struggling, and indeed are still struggling, against outright denial, geopolitics and misplaced caution in order to achieve global recognition. Interestingly, these other museums fit far more squarely in Louis Bickford and Amy Sodaro's 'new commemorative paradigm' in memorial museums - which, crucially, they define as a strategy of memorialisation in societies transitioning from conflict, dictatorship and authoritarianism which aims to help communities in confronting and coming to terms with the past. ${ }^{32}$ Since the Ottoman past is not just unconfronted but still hotly contested, one can begin to understand these differences in the AGMI's exhibition. ${ }^{33}$

prosecuted, accusing them of propagating relativism, genocide denial, and the 'double genocide theory'. See Lars Waldorf, “Instrumentalising Genocide: The RPF's Campaign against 'Genocide Ideology," in Remaking Rwanda: State Building and Human Rights After Mass Violence, eds. Scott Straus and Lars Waldorf (Wisconsin: University of Wisconsin Press, 2011).

31. Paul B. Miller, "Contested Memories: The Bosnian Genocide in Serb and Muslim Minds," Journal of Genocide Research 8:3 (2006): 311-24.

32. Bickford and Sodaro, "Remembering Yesterday to Protect Tomorrow," 68-9. These museums, they argue, operate under the rubric of 'never again', and try to prevent atrocities and genocide in the future via education, experience, and empathy: by educating younger generations about past injustices, by encouraging them to 'experience' the past for themselves at immersive museums, and by creating empathy with the victims through displays of personal belongings, family photographs, and lists of names, these museums hope to enact a moral transformation in their visitors which will encourage them to take action against genocide and promote democratic values (77-82). Quite correctly, the question the ability of these techniques alone to inspire the kind of moral transformation in their visitors which will encourage them to take action against genocide, and promote democratic values (82-3).

33. The AGMI is thus an excellent example which shows us very clearly the limits of this paradigm's applicability in cases of contested pasts. Other examples of 'contested pasts' which reinforce my point: in ways not dissimilar to the Armenian case, for example, in present-day Spain there is so little agreement about the Civil War of 1936-39 and its aftermath that a museum along the lines of the 'new commemorative paradigm' would only be met with deeper contestation. See Helen Graham, The War and its Shadow: Spain's Civil War in Europe's Long Twentieth Century (Eastbourne: Sussex Academic Press, 2012), especially chapter 7. Somewhat differently, Lithuania's Museum of Genocide Victims in Vilnius is hardly an example of the more open 'confronting of the past' which the paradigm suggests, since it minimises the (mainly Jewish and communist) victims of the Nazis' cleansing policies, in favour of emphasising the repression of Lithuanian national identity and the Lithuanians killed under the Soviet regime. See A. Craig Wight and J. John Lennon, "Selective interpretation and eclectic human heritage in Lithuania," Tourism Management 28 (2007): 519-29. 


\section{Conclusion: the visitors}

The concept of 'familiarity' is always quite useful to think about when considering how visitors might respond to a museum, but, as we will see, is particularly apt in the case of the AGMI because of the nature of its visitor base (which is primarily Armenian, but also includes a fairly large number of non-Armenians - mostly European or North American and the many foreign delegates who are taken on a tour of the museum as part of the official State protocol). At the time of its opening and increasingly so since, most Western visitors would in all likelihood have visited at least one Holocaust museum before, and would have noticed some of the differences in exhibition style discussed above - but more importantly they will also have arrived with a passing knowledge of the Holocaust, gleaned from popular films such as Schindler's List, various literature including survivor testimonies, and these museums. This passing knowledge of the Holocaust underpins most Westerners' conception of genocide - as the mass killing of a minority group by a fanatical state ${ }^{34}$ - and although few will know much of the history of the Armenian genocide, the text and images which they encountered in the AGMI exhibition will certainly have seemed familiar, and fitted easily into this general conception of genocide.

Since we can assume that Armenians do not need convincing that these events constitute genocide, it is worth considering what they might nevertheless have taken from the exhibition and memorial complex. ${ }^{35}$ In part, visiting the exhibition and the memorial complex can act as a confirmation of identity, and joining the commemorative march on April $24^{\text {th }}$ is in a sense a performance of duty. The exhibition narrative itself will of course have been extremely familiar to most Armenian visitors; the events it covered were, in fact, a very basic and standard narrative of the genocide, since (for example) there was little detail on the individual histories of deportation and massacre from the areas now in Turkey, in which the relatives of many visiting diaspora Armenians will have been born. ${ }^{36}$ What the exhibition provided visitors with was the opportunity to engage with the authentic objects which narrated their history: although some of the visitors I observed in April 2011 wandered through the exhibition without really pausing (I suspect because they had seen it many times before), ${ }^{37}$ many also seemed to be engrossed in discussing individual items in the display cases.

In this sense, the exhibition did very much function as a guardian of meaning and memory, as I suggested in the introduction. Memorial museums increasingly need to be

34. The UN Genocide Convention's definition (and that of genocide scholars) is of course much broader than this - and indeed the AGMI exhibition also provides evidence for genocide as the destruction of cultural buildings and as the forcible removal of children from one group to another.

35. Of course, these encounters and experiences will also change over time and depending on context. See Darieva's discussion of how interpretations of the symbolism behind the obelisk and eternal flame have evolved since 1967 - through Soviet rule and during the Karabagh movement - in "The road to Golgotha," 98.

36. Raymond H. Kévorkian's comprehensive The Armenian Genocide: A Complete History (London: I.B. Tauris, 2011), provides such detail.

37. In this sense, the visit to the museum on April 24th really does seem as a 'performance of duty'. 
analysed and understood from a global or transnational perspective - both because they themselves are part of global trends, and because their visitors are also often from different corners of the globe - but this case study also shows how deep an impact specific national contexts and histories, and the contestation of those histories, can have on the remembrance and representation of genocide. 